JURNAL KEBIDANAN

Vol 5, No 4, Oktober 2019 : 396-402

\title{
SURVEI KUALITAS GIZI MAKANAN SELA YANG DIKONSUMSI SISWI SMP DAN SMA
}

\author{
Alifia Nanda Brillianty1), Neneng Martini2), Puspa Sari33), Didah4), Sri Astuti(5) \\ ${ }^{1}$ Program Pendidikan Diploma IV Kebidanan Fakultas Kedokteran, Universitas Padjadjaran \\ Email: alifiananda91@gmail.com \\ 2Departemen IImu Kesehatan Masyarakat, Fakultas Kedokteran, Universitas Padjadjaran \\ Email: Neneng_martini@yahoo.co.id \\ 32Departemen IImu Kesehatan Masyarakat Fakultas Kedokteran Universitas Padjajaran \\ Email: saripuspabidan2@gmail.com \\ ${ }^{4}$ Departemen IImu Kesehatan Masyarakat Fakultas Kedokteran Universitas Padjajaran \\ Email: didahramdani@gmail.com \\ ${ }^{5}$ Departemen IImu Kesehatan Masyarakat Fakultas Kedokteran Universitas Padjajaran \\ Email: Sriastuti29@gmail.com
}

\begin{abstract}
Introduction: Adolescence is a period of growth, and development both physically, psychologically, and intellectually. Therefore, the nutrients needed are higher. Teenagers's habits is eating meals at school and outside the school known as snack food. This study aims to determine the type, nutrient content, nutritional quality, the amount of interrupted food and the consideration of choosing the food consumed by middle and high school students in Jatinangor Subdistrict.

Method: The research method used descriptive surveys with primary data interviewed by 332 respondents. Processing data using nutri survey.

Results: The results showed that the type of food most often consumed was fried meatballs with 65 respondents (19.57\%), no food that fulfilled all nutritional adequacy rates, 295 respondents (88.9\%) consumed non-quality food, 187 respondents (56.3\%) ate 3-5 types of food, 222 respondents (66.9\%) chose consideration of good taste

Conclusion: The most often consumed is fried meatballs with 65 respondents (19.57\%), no food that fulfilled all nutritional adequacy figures, 295 respondents (88.9\%) consumed non-quality food, 187 respondents (56.3\%) ate 3-5 types of food, 222 respondents (66.9\%) choose consideration good taste

Sugestion: Middle and high school students should sort out the interrupted food consumed and must consider the nutrition contained in it because the nutritional quality of interrupted food consumed is very influential on the health of adolescent girls, especially for the period of pregnancy
\end{abstract}

Keywords: Nutritional quality, snack food, adolescents

\section{ABSTRAK}

Latar Belakang: Masa remaja merupakan periode terjadinya pertumbuhan, dan perkembangan baik secara fisik, psikologis, maupun intelektual. Oleh karena itu, nutrisi yang dibutuhkan lebih tinggi. Remaja mempunyai kebiasaan makan diantara waktu makan baik berupa jajanan disekolah maupun diluar sekolah yang dikenal dengan makanan sela. Penelitian ini bertujuan untuk mengetahui jenis, kandungan gizi, kualitas gizi, banyaknya makanan sela serta pertimbangan memilih makanan sela yang dikonsumsi siswi SMP dan SMA di Kecamatan Jatinangor.

Metode: Metode penelitian menggunakan survei deskriptif dengan data primer hasil wawancara 332 responden. Pengolahan data menggunakan nutri survey.

Hasil: Hasil penelitian menunjukkan jenis makanan yang paling sering dikonsumsi adalah baso goreng dengan 65 responden $(19,57 \%)$, tidak ada makanan yang memenuhi seluruh angka kecukupan gizi, 295 responden $(88,9 \%)$ mengonsumsi makanan sela yang tidak berkualitas, 187 responden $(56,3 \%)$ memakan 3-5 jenis makanan, 222 responden $(66,9 \%)$ memilih pertimbangan rasa yang enak

Kesimpulan: Makanan yang paling sering dikonsumsi adalah baso goreng dengan 65 responden $(19,57 \%)$. tidak ada makanan yang memenuhi seluruh angka kecukupan gizi, 295 responden $(88,9 \%)$ mengonsumsi makanan sela yang tidak berkualitas, 187 responden (56,3\%) memakan 3-5 jenis makanan, 222 responden $(66,9 \%)$ memilih pertimbangan rasa yang enak. 
Saran: Sebaiknya siswi SMP dan SMA lebih memilah kembali makanan sela yang dikonsumsi nya dan harus mempertimbangkan gizi yang terdapat didalamnya karena kualitas gizi makanan sela yang dikonsumsi sangat berpengaruh pada kesehatan remaja putri terutama untuk dimasa kehamilan

Kata Kunci: Kualitas gizi, makanan sela, remaja

\section{PENDAHULUAN}

Masa remaja merupakan periode terjadinya pertumbuhan, dan perkembangan baik secara fisik, psikologis, maupun intelektual. Oleh karena itu, nutrisi yang dibutuhkan sedikit lebih tinggi untuk memenuhi kebutuhan pertumbahan dan perkembangan remaja tersebut.

Asupan makanan atau asupan gizi merupakan salah satu faktor utama yang mempengaruhi status gizi. ${ }^{3}$ Remaja mempunyai kebiasaan makan di antara waktu makan, berupa jajanan baik di sekolah maupun di luar sekolah. Makanan yang dikonsumsi diluar kebiasaan makan (menu utama) ini dikenal dengan istilah makanan sela.

Survei tentang asupan gizi di Amerika Serikat menunjukkan bahwa remaja cenderung mendapat asupan vitamin A, tiamin besi, dan kalsium lebih sedikit dari yang dianjurkan.Kebanyakan remaja umumnya suka makan di luar rumah, mereka memiliki kesenangan untuk mengonsumsi makanan dari pinggir jalan maupun makanan cepat saji (Junk Food) Makanan jajanan yang dijual oleh kantin sekolah nampaknya menjual makanan dengan kandungan energi dan lemak yang tinggi, tetapi rendah serat, vitamin, dan mineral.

Masalah gizi yang terjadi pada masa remaja diantaranya adalah gizi kurang, obesitas, dan anemia. Menurut data Riset Kesehatan Dasar Republik Indonesia (Riskesdas RI) 2013, kelompok umur 13-15 tahun penilaian status gizi berdasarkan IMT, prevalensi nasional kurus pada remaja umur 13-15 tahun adalah $11,1 \%$ terdiri dari 3,3\% sangat kurus dan $7,8 \%$ kurus. Sedangkan untuk kasus obesitas di Indonesia, secara nasional masalah gemuk pada anak umur 5-12 tahun masih tinggi yaitu 18,8 persen, terdiri dari gemuk 10,8 persen dan sangat gemuk (obesitas) 8,8 persen. ${ }^{7}$. Terlihat dari Studi Diet Total (SDT 2014) bahwa konsumsi makanan yang tinggi gula, garam, dan lemak transfat pada kelompok usia tersebut juga tinggi. Prevalensi kurus pada remaja umur 13-15 tahun di Jawa Barat adalah 9,1\% terdiri dari 2,6\% sangat kurus dan 6,5\% kurus. Prevalensi gemuk pada remaja umur 13-15 tahun di Jawa Barat sebesar $9.7 \%$, terdiri dari $7,5 \%$ gemuk dan $2,5 \%$ sangat gemuk (obesitas).
Prevalensi kurus pada remaja umur 16-18 tahun secara umum sebesar $9,1 \%(1,4 \%$ sangat kurus dan $7,7 \%$ kurus). Prevalensi gemuk pada remaja umur 16 - 18 tahun di Jawa Barat sebanyak $7,6 \%$ yang terdiri dari $6,2 \%$ gemuk dan $1,4 \%$ obesitas.

Masalah lain yang biasanya dialami remaja adalah anemia. Pada saat itu pula, remaja putri mengalami menstruasi yang dapat menyebabkan individu tersebut kehilangan banyak zat besi dalam tubuhnya. Sekitar $43 \%$ dari kematian remaja terkait dengan kehamilan. Kehamilan pada masa remaja menghalangi anak-anak mencapai pertumbuhan penuh mereka.

Menurut WHO, kasus anemia pada tahun 2011 29\% (496 juta) wanita tidak hamil dan 38\% (32,4 juta) wanita hamil berusia 15-49 tahun mengalami anemia. Menurut data dari Riskesdas tahun 2013, prevalensi anemia di Indonesia yaitu $26,4 \%$ untuk penderita berumur 5-14 tahun dan $18,4 \%$ untuk penderita berumur 15-24 tahun. Resiko paling tinggi terkena anemia yaitu remaja putri. Dapat dilihat dari data Riskesdas 2013, terdapat $23,9 \%$ perempuan dengan kadar hemoglobin kurang dari $11,0 \mathrm{gr} / \mathrm{dL}$ sementara hanya terdapat $18,4 \%$ laki-laki yang mengalami anemia.

Dampak anemia pada remaja putri dan status gizi yang buruk memberikan kontribusi negatif bila hamil pada usia remaja ataupun dewasa yang dapat menyebabkan kelahiran bayi dengan berat badan lahir rendah, kesakitan bahkan kematian pada ibu maupun bayi.

Menurut penelitian di Semarang yang dilakukan oleh Adriyan dan Sulchan, makanan jajanan lokal dapat menyebabkan masalah gizi remaja diantaranya obesitas. Menurut penelitian yang dilakukan oleh Dwiningsih dan Adriyan, di SMP Negeri 3 Mojogedang dan SMP Negeri 3 Semarang menunjukan bahwa remaja di kota dan di desa sama-sama sering mengonsumsi makanan sela seperti mie, bakso, gorengan, dan makanan ringan lainnya dan hasilnya adalah status gizi remaja perkotaan lebih banyak yang mengalami obesitas, sementara remaja di pedesaan lebih banyak yang mengalami gizi kurang karena secara tidak langsung tempat tinggal berpengaruh dengan kejadian overweight maupun obesitas pada usia remaja, karena di kota akses, distribusi dan 
pemilihan makanan lebih banyak dibandingkan dengan di desa. Usia remaja merupakan usia dimana mereka sangat tertarik pada hal-hal baru dan sebagian besar terpengaruh dengan lingkungan sekitar dan teman sebaya.

Berdasarkan latar belakang di atas, penulis tertarik untuk meneliti survei kualitas gizi makanan sela yang dikonsumsi siswi SMP dan SMA di Jatinangor.

\section{METODE PENELITIAN}

Penelitian yang dilakukan adalah penelitian survey deskriptif yang dilakukan tanpa melakukan intervensi pada subjek dan hanya mengambil sebagian subjek yang diteliti, menggunakan analisis deskriptif, dan menggunakan data primer dengan kuesioner.

Subjek penelitian yang digunakan adalah siswi SMP dan SMA di Kecamatan Jatinangor yang mengonsumsi makanan sela sebanyak 332 responden.

Teknik pengambilan sampel pada penelitian ini adalah secara berstrata dan purposive sampling yaitu ditentukan strata karakteristik untuk lalu dilanjutkan dengan penentuan sampel oleh orang yang mengenal populasi yang akan diteliti.

Instrumen yang digunakan dalam penelitian ini adalah kuesioner. Kuesioner diisi dengan menuliskan makanan yang dikonsumsi 1 (satu) hari sebelum penelitian dilakukan. Data yang dikumpulkan, diolah dan dianalisis dengan komputerisasi. Pengolahan kandungan gizi dan kualitas gizi menggunakan aplikasi nutri survey untuk menentukan kandungan gizi lalu dibandingkan dengan Angka Kecukupan Gizi makanan sela setiap harinya.

\section{HASIL DAN PEMBAHASAN}

Telah dilakukan penelitian mengenai kualitas gizi makanan sela yang dikonsumsi siswi SMP dan SMA di Kecamatan Jatinangor. Pengambilang sample dilakukan pada 332 orang responden yang terpilih di SMPN 1, SMPN 2, SMPN 3 dan SMAN Jatinangor di Kecamatan Jatinangor

Jenis Makanan Sela yang Dikonsumsi

Tabel 1 Distribusi Frekuensi Jenis Makanan Sela yang Sering Dikonsumsi Siswi SMP dan SMA di Kecamatan Jatinangor

\begin{tabular}{ccc}
\hline \multirow{2}{*}{ Jenis Makanan Sela } & \multicolumn{2}{c}{ Jumlah } \\
\cline { 2 - 3 } & $\mathrm{n}$ & $\%$ \\
\hline Baso Goreng & 65 & 19,57 \\
Gehu & 58 & 17,46 \\
Susu & 45 & 13,55 \\
Roti Coklat & 42 & 12,65 \\
Cimol & 40 & 12,04 \\
Bakwan & 39 & 11,7 \\
Gorengan Tempe & 32 & 9,63 \\
Cireng & 30 & 9,03 \\
Energen & 30 & 9,03 \\
Mie Kuah & 27 & 8,13 \\
\hline
\end{tabular}

Berdasarkan tabel 1, didapatkan hasil 10 jenis makanan sela yang paling sering dikonsumsi oleh siswi SMP dan SMA di Kecamatan Jatinangor, adalah baso goreng (basreng) sebanyak 65 responden $(19,57 \%)$ dan yang paling sedikit adalah mie kuah sebanyak 27 responden $(8,13 \%)$.

\section{Kandungan Gizi Makanan Sela}

Tabel 2 Distribusi Frekuensi Kandungan Zat Gizi yang Terdapat dalam Makanan yang Sering Dikonsumsi Siswi SMP

\begin{tabular}{ccccccccc}
\hline Jenis Makanan & $\begin{array}{c}\text { Kalori } \\
(173,3)\end{array}$ & $\begin{array}{c}\text { Protein } \\
(5,04)\end{array}$ & $\begin{array}{c}\text { Lemak } \\
(5,81)\end{array}$ & $\begin{array}{c}\text { Karbohidrat } \\
(23,8)\end{array}$ & $\begin{array}{c}\text { Vit A } \\
(56)\end{array}$ & $\begin{array}{c}\text { Vit C } \\
(3,5)\end{array}$ & $\begin{array}{c}\text { Kalsium } \\
(84)\end{array}$ & $\begin{array}{c}\text { Zat Besi } \\
(1,05)\end{array}$ \\
\hline Baso Goreng & 359,1 & 2,4 & 5,3 & 73 & 4,3 & 0 & 6,4 & 0,5 \\
Gehu & 103,6 & 3,7 & 8,4 & 4,7 & 0,1 & 0,4 & 40,5 & 2,2 \\
Susu & 131,9 & 6,4 & 7,8 & 9,6 & 110 & 2 & 230 & 0,2 \\
Roti Coklat & 213 & 6,5 & 3,2 & 39,4 & 0 & 0 & 8,3 & 0,5 \\
Cimol & 381 & 0,3 & 0,1 & 91,3 & 0 & 0 & 2 & 0,5 \\
Bakwan & 539,9 & 5,3 & 40,5 & 39,2 & 0 & 1 & 10 & 0,6 \\
Gorengan Tempe & 177 & 8,6 & 13,4 & 7,7 & 0,5 & 0 & 42 & 1 \\
Cireng & 95,2 & 0,1 & 0 & 22,8 & 0 & 0 & 0,5 & 0,1 \\
Energen & 130 & 1 & 3,5 & 24 & 0,3 & 0 & 0,2 & 0 \\
Mie Kuah & 141 & 4,8 & 0,7 & 28,3 & 0 & 0 & 7 & 0,5 \\
\hline
\end{tabular}


Dari tabel 2 diatas didapatkan hasil bahwa makanan yang sering dikonsumsi oleh siswi SMP di Kecamatan jatinangor tidak ada yang semua kandungan gizi nya memenuhi $7 \%$ angka kecukupan gizi untuk makanan sela.

Tabel 3 Distribusi Frekuensi Kandungan Zat Gizi yang Terdapat dalam Makanan yang Sering dikonsumsi Siswi SMA

\begin{tabular}{ccccccccc}
\hline Jenis Makanan & $\begin{array}{c}\text { Kalori } \\
(187,3)\end{array}$ & $\begin{array}{c}\text { Protein } \\
(4,62)\end{array}$ & $\begin{array}{c}\text { Lemak } \\
(6,23)\end{array}$ & $\begin{array}{c}\text { Karbohidrat } \\
(25,76)\end{array}$ & $\begin{array}{c}\text { Vit } \\
\text { A } \\
(56)\end{array}$ & $\begin{array}{c}\text { Vit C } \\
(4,2)\end{array}$ & $\begin{array}{c}\text { Kalsium } \\
(84)\end{array}$ & $\begin{array}{c}\text { Zat Besi } \\
(1,05)\end{array}$ \\
\hline Baso Goreng & 359,1 & 2,4 & 5,3 & 73 & 4,3 & 0 & 6,4 & 0,5 \\
Gehu & 103,6 & 3,7 & 8,4 & 4,7 & 0,1 & 0,4 & 40,5 & 2,2 \\
Susu & 131,9 & 6,4 & 7,8 & 9,6 & 110 & 2 & 230 & 0,2 \\
Roti Coklat & 213 & 6,5 & 3,2 & 39,4 & 0 & 0 & 8,3 & 0,5 \\
Cimol & 381 & 0,3 & 0,1 & 91,3 & 0 & 0 & 2 & 0,5 \\
Bakwan & 539,9 & 5,3 & 40,5 & 39,2 & 0 & 1 & 10 & 0,6 \\
Gorengan Tempe & 177 & 8,6 & 13,4 & 7,7 & 0,5 & 0 & 42 & 1 \\
Cireng & 95,2 & 0,1 & 0 & 22,8 & 0 & 0 & 0,5 & 0,1 \\
Energen & 130 & 1 & 3,5 & 24 & 0,3 & 0 & 0,2 & 0 \\
Mie Kuah & 141 & 4,8 & 0,7 & 28,3 & 0 & 0 & 7 & 0,5 \\
\hline
\end{tabular}

Dari tabel 3 diatas didapatkan hasil bahwa makanan yang sering dikonsumsi oleh siswi SMA di Kecamatan jatinangor tidak ada yang semua kandungan gizi nya memenuhi $7 \%$ angka kecukupan gizi untuk makanan sela.

\section{Kualitas Gizi Makanan Sela}

Tabel 4 Kualitas Gizi Makanan Sela yang Dikonsumsi

\begin{tabular}{ccc}
\hline \multirow{2}{*}{ Kualitas Gizi } & \multicolumn{2}{c}{ Jumlah } \\
\cline { 2 - 3 } & $\mathrm{n}$ & $\%$ \\
\hline Berkualitas & 35 & 10,5 \\
Tidak Berkualitas & 297 & 89,5 \\
Jumlah & 332 & 100 \\
\hline
\end{tabular}

Berdasarkan tabel 4 dinyatakan bahwa lebih banyak responden yang mengonsumsi makanan yang tidak berkualitas yaitu sebanyak 297 responden $(89,5 \%)$.

Tabel 5 Banyaknya Jenis Makanan Sela yang Dikonsumsi

\begin{tabular}{ccc}
\hline Banyaknya Jenis & \multicolumn{2}{c}{ Jumlah } \\
\cline { 2 - 3 } Makanan Sela & $\mathrm{n}$ & $\%$ \\
\hline$<3$ & 103 & 31 \\
$3-5$ & 187 & 56,3 \\
$>5$ & 42 & 12,7 \\
Jumlah & 332 & 100 \\
\hline
\end{tabular}

Berdasarkan tabel 5 dinyatakan bahwa responden yang mengonsumsi makanan sela paling banyak memakan 3-5 jenis makanan sela dengan jumlah 187 responden $(56,3 \%)$.

Tabel 6 Pertimbangan Pemilihan Makanan Sela yang Dikonsumsi

\begin{tabular}{ccc}
\hline \multirow{2}{*}{ Pertimbangan } & \multicolumn{2}{c}{ Jumlah } \\
\cline { 2 - 3 } & $\mathrm{n}$ & $\%$ \\
\hline Rasa yang enak & 222 & 66,9 \\
Harga yang sesuai & 27 & 8,1 \\
Gizi yang terdapat dalam makanan & 52 & 15,7 \\
Lainnya & 31 & 9,3 \\
Jumlah & 332 & 100 \\
\hline
\end{tabular}

Berdasarkan tabel 6 diatas, didapatkan bahwa pertimbangan pemilihan makanan sela terbanyak adalah adalah sebanyak 222 responden $(66,9 \%)$ memilih makanan sela dengan rasa yang enak.

\section{Jenis Makanan Sela yang Dikonsumsi}

Berdasarkan hasil penelitian yang dilakukan, didapatkan hasil bahwa siswi SMP dan SMA lebih sering mengonsumsi makanan sela berupa jajanan yang dikonsumi di sekolah. Siswi SMP dan SMA paling sering mengonsumsi baso goreng, gehu, susu, dll. Kebiasaan makan masyarakat dengan susunan hidangannya merupakan manifestasi dari kebudayaan masyarakat yang disebut life style atau gaya hidup..$^{14}$

Makanan yang dianggap makanan ringan ini dikonsumsi untuk menghilangkan rasa lapar 
sementara waktu, memberi sedikit energi untuk tubuh atau hanya sekedar menikmati rasa. ${ }^{15} \mathrm{Hal}$ ini akan menimbulkan masalah yang akan terjadi pada remaja diantaranya ketidak seimbangan antara asupan kebutuhan atau kecukupan yang akan menimbulkan masalah gizi lebih atau gizi kurang. ${ }^{16}$

\section{Kandungan Gizi Makanan Sela}

Hasil penelitian menunjukkan hasil bahwa tidak ada makanan sela yang dikonsumsi siswi SMP dan SMA di Kecamatan Jatinangor yang memenuhi $7 \%$ angka kecukupan gizi untuk makanan sela. Dari hasil penelitian yang didapatkan, bahwa kandungan gizi makanan sela yang dikonsumsi sebagian besar memenuhi kebutuhan gizi makro bahkan melebihi angka kecukupan gizi makanan sela. Hal ini bisa menyebabkan obesitas pada remaja. Penderita obesitas mempunyai status nutrisi yang melebihi kebutuhan metabolisme karena kelebihan masukan kalori dan/atau penurunan penggunaan kalori, artinya masukan kalori tidak seimbang dengan penggunaannya yang pada akhirnya berangsurangsur berakumulasi meningkatkan berat badan. ${ }^{6}$

Hasil penelitian ini dapat didkukung oleh hasil penelitian yang dilakukan oleh Lilis Heryati dan Budi Setiawan di Kota Bogor pada tahun 2014 didapatkan hasil bahwa terdapat perbedaan yang signifikan antara asupan energi, protein dan lemak pada subjek normal dan kegemukan. ${ }^{17}$

Asupan kandungan gizi mikro yang didapatkan dari hasil penelitian menyatakan bahwa kebanyakan asupan gizi nya tidak memenuhi $7 \%$ AKG. Hal ini dapat menyebabkan beberapa masalah pada remaja diantaranya anemia karena kekurangan suatu zat yaitu zat besi.

Kekurangan zat besi dalam makanan seharihari dapat menimbulkan kekurangan darah yang dikenal sebagai Anemia Gizi Besi (AGB). Remaja putri lebih rawan mengalami anemia karena remaja putri mengalami menstruasi/haid berkala yang mengeluarkan sejumlah zat besi setiap bulan. ${ }^{6}$

\section{Kualitas Gizi Makanan Sela}

Berdasarkan hasil penelitian yang dilakukan didapatkan hasil dari 332 responden hanya ada 35 responden yang mengonsumsi makanan sela yang berkualitas sementara 297 responden lagi tidak. Menurut World Health Organization (WHO), proporsi pemenuhan zat-zat gizi dalam sehari berasal dari: sarapan memberikan $14 \%$, makan siang memberikan 44\%, makan selingan memberikan 14\% (masing-masing $7 \%$ untuk selingan pagi dan sore) dan makan malam memberikan $28 \%$, sehingga makanan selingan yang dikonsumsi oleh siswi SMP dan SMA harus memenuhi 7\% dari Angka Kecukupan Gizi (AKG) yang telah ditetapkan. ${ }^{18}$

Beberapa faktor yang dapat mempengaruhi pola makan remaja terutama dalam mengonsumsi makanan cepat saji (fast food) antara lain umur, pengetahuan gizi, jumlah uang saku, pendapatan orang tua, kegiatan, pola makan, dan status kegemukan. Pengaruh lingkungan dan teman sebaya lebih dominan dibandingkan ilmu yang mereka punya, sehingga pemilihan makanan tidak lagi didasari pada kandungan gizi melainkan sekedar sosialisasi untuk kesenangan. ${ }^{19}$

Berdasarkan penelitian yang dilakukan oleh Farah dkk pada tahun 2016 menyatakan bahwa remaja yang belum mencukupi kebutuhan energi sebesar $97,5 \%$ dan sisanya memiliki tingkat kecukupan energi yang baik. ${ }^{20}$

Remaja putri juga biasanya ingin kurus sehingga berdiet dengan mengurangi makan. Diet yang tidak seimbang dengan kebutuhan tubuh akan menyebabkan tubuh kekurangan zat penting seperti zat besi. ${ }^{6}$ Jika hal ini berlanjut dalam jangka waktu yang cukup lama, akan menyebabkan menurunnya berat badan yang berlanjut pada gizi kurang yang akan menghambat proses pertumbuhan dan perkembangan. ${ }^{20}$ Sedangkan, kebutuhan gizi remaja lebih tinggi untuk memenuhi kebutuhan pertumbahan dan perkembangan remaja tersebut. ${ }^{2}$

Hasil ini sejalan dengan penelitian yang dilakukan oleh Ulfa Aprilila pada tahun 2013 di Bekasi yang menunjukkan hasil bahwa dari 42 responden hanya ada 1 responden yang makanan sela yang dikonsumsi nya berkualitas. ${ }^{21}$

\section{Banyaknya Jenis Makanan Sela yang Dikonsumsi}

Berdasarkan tabel diatas, didapatkan hasil bahwa sebagian besar responden mengonsumsi 35 jenis makanan sela per hari. Remaja yang lebih banyak mengonsumsi makanan sela akan berdampak buruk pada kesehatannya karena hanya akan membuat perut kenyang, namun nafsu makan nya akan terganggu dan kesehatannya pun terganggu karena kandungan gizi yang tidak baik didalamnya. Makanan sela pun dapat menjadi pemicu obesitas karena terlalu tinggi nya jumlah kalori di dalamnya. ${ }^{9}$

Untuk kasus gangguan pola makan pada remaja, British Medical Association mengemukakan bahwa citra wanita kurus dan ramping yang digambarkan oleh media masa bisa merupakan pendorong para remaja untuk menjalani pola makan yang tidak benar. Dampak yang akan ditimbulkan jika terjadi ketidakseimbangan asupan zat gizi pada 
remaja akan menghambat proses pertumbuhan dan perkembangan (growth spurt) dan pada remaja putri masih mempunyai dampak lain, karena remaja putri sebagai generasi muda juga akan melahirkan calon generasi muda. ${ }^{22}$

\section{Pertimbangan Pemilihan Makanan Sela yang Dikonsumsi}

Berdasarkan hasil penelitian didapatkan hasil kebanyakan remaja mementingkan makanan dengan rasa yang ada pada makanan sela tersebut dibandingkan mempertimbangkan kualitas gizi yang ada didalamnya. Hal ini dapat berpengaruh dari usia remaja dimana mereka sangat tertarik pada hal-hal baru dan sebagian besar terpengaruh dengan lingkungan sekitar dan teman sebaya. ${ }^{12}$ Seharusnya, pemilihan makanan sela disesuaikan dengan fungsinya diantaranya mencukupi asupan nutrisi yang mungkin kurang, ke-aneka ragaman jenis makanan yang terdapat dalam makanan selingan, mengatasi masalah anak yang sulit makan nasi, serta untuk mencukupi kebutuhan kalori terutama pada anak yang banyak melakukan aktivitas. $^{15}$

Hasil penelitian ini sejalan dengan penelitian yang dilakukan oleh Sela Ovina, dkk yang menunjukkan hasil bahwa sebanyak 99 orang dari 313 orang responden $(37,515 \%)$ memilih makanan sela berdasarkan The Familiarity, Convenience, and Comfort of Food (Keakraban, Kenyamanan, dan Kenikmatan) dari setiap makanan, dan hal tersebut yang mendominasi pemilihan makanan dari responden..$^{23}$

\section{SIMPULAN}

Jenis makanan sela yang paling sering dikonsumsi oleh siswi SMP dan SMA di Kecamatan Jatinangor adalah baso goreng sebanyak 65 responden (19,57\%).Kandungan gizi makanan sela yang paling sering dikonsumsi oleh siswi SMP dan SMA di Kecamatan Jatinangor adalah tidak ada makanan sela yang kandungan gizi nya memenuhi angka kecukupan gizi makanan sela. Kualitas gizi makanan sela yang dikonsumsi siswi SMP dan SMA di Kecamatan Jatinangor pada umumnya belum berkualitas dengan hasil 295 responden $(88,9 \%)$.Lebih banyak responden yang mengonsumsi makanan sela sebanyak 3-5 jenis makanan dengan jumlah 187 responden (56,3\%).Pertimbangan pemilihan makanan sela yang dilakukan responden paling banyak memilih karena berdasarkan cita rasa yang dimiliki makanan tersebut dengan jumlah 222 responden $(66,9 \%)$.

\section{SARAN}

Sebaiknya siswi SMP dan SMA lebih memilah kembali makanan sela yang dikonsumsi nya dan harus mempertimbangkan gizi yang terdapat didalamnya karena kualitas gizi makanan sela yang dikonsumsi sangat berpengaruh pada kesehatan remaja putri terutama untuk dimasa kehamilan.Sebaiknya tenaga pendidik (guru) lebih memperhatikan makanan sela atau jajanan yang terdapat di sekolah dan lebih memberi informasi pada siswa maupun siswi nya mengenai gizi yang terkandung dalam makanan serta manfaat dan dampaknya bagi tubuh. Tenaga pendidik juga bekerja sama dengan kantin di sekolah agar menjual makanan sela yang kandungan gizinya baik. Selain itu guru dapat memberikan promosi kesehatan atau edukasi siswi maupun petugas di kantin sekolah mengenai gizi yang baik khususnya pada makanan sela. Orang tua sebaiknya lebih memperhatikan makanan sela apa yang dikonsumsi oleh anaknya. Sebaiknya orang tua memberi bekal pada anaknya agar lebih menjamin kualitas gizi yang baik.

\section{DAFTAR PUSTAKA}

Adriani M, Wirjatmadi B. Peranan Gizi dalam Siklus Kehidupan. Jakarta: Kencana, 2012

Aprilila U, Setiawan B, Amalia L. Kualitas makanan selingan pagi anak prasekolah pada pendidikan anak usia dini (paud) bougenvil kota bekasi. Skripsi: Departemen Gizi Masyarakat Fakultas Ekologi Manusia Institut Pertanian Bogor, 2013

Aulia G, Udiyono A, Saraswati L, Adi M. Gambaran status anemia pada remaja putri di wilayah pegunungan dan pesisir pantai (studi di SMP negeri kecamatan getasan dan semarang barat). Jurnal Kesehatan Masyarakat 2017; 5

Desri S, Hafiani R, dan Junita R. Analisis Pola Makan dan Anemia Gizi Besi pada Remaja Putri Kota Bengkulu. Bengkulu. 2015; 10

Dinas Kesehatan Propinsi Jawa Barat. 2016

Dwiningsih, Pramono A. Perbedaan asupan energi, protein, lemak, karbohidrat, dan status gizi pada remaja yang tinggal di wilayah perkotaan dan pedesaan (studi di SMP negeri 3 Semarang dan SMP negeri 3 Mojogedang). Journal of Nutrition College 2013. 2: 232-241

Heryati L, Setiawan B. Kegemukan, anemia, dan prestasi belajar siswa sekolah dasar di kota bogor. Jurnal Gizi Pangan. 2014:9(3)

Imanuel Kant, A.J. Pandelaki, B.S. Gambaran kebiasaan makan masyarakat di perumahan allandrew permai kelurahan malalayang I 
lingkungan $\mathrm{XI}$ kota manado. Jurnal Kedokteran Komunitas dan Tropik 2013:3A

Kementrian Kesehatan RI. INFODATIN Pusat Data dan Informasi Kementrian Kesehatan RI Situasi Kesehatan Reproduksi Remaja. 2015.

Larega, T. Pengaruh Sarapan Terhadap Tingkat Konsentrasi pada Remaja. J MAJORITY 2015: 4

Lusiana N, Andriyani R, Megasari M. Buku ajar metodologi pelatihan kebidanan. Yogyakarta: Deepublish, 2015

Mahpolah, dkk. Faktor-faktor yang berhubungan dengan kebiasaan mengkonsumsi fast food pada remaja sma kartika v-1 balikpapan

Mokoginta F, dkk. Gambaran pola asupan makanan pada remaja di kabupaten bolaang mongondow utara. Jurnal e-biodemik. 2016:4(2)

Mutumanikam R, Isnaeni F, Rusdjianto. Kontribusi asupan makanan selingan teradap presentase angka kecukupan gizi pada anak usia prasekolah di kelurahan semanggi dan sangkrah kecamatan pasar kliwon surakarta. Naskah Publikasi: Fakultas IImu Kesehatan, 2013

Ovina S, dkk. Faktor faktor yang mempengaruhi pemilihan makanan pada remaja di surabaya. Jurnal Hospitality dan Manajemen Jasa 2018:6

Pramono A, Sulchan M. Kontribusi makanan jajan dan aktivitas fisik terhadap kejadian obesitas pada remaja di kota semarang. Gizi Indon 2014 2: 129-136

Pujianti, Arneliwati, Rahmalia S. Hubungan antara perilaku makan dengan status gizi pada remaja. JOM 2015;2

Rinanti O. Hubungan asupan zat gizi makro dan pengetahuan gizi seimbang dengan status gizi siswa-siswi di SMP Muhammadiyah 1 Kartasura. Diploma thesis, Universitas Muhammadiyah Surakarta. 2014

Silalahio V, Aritonang E, Ashar T. Potensi pendidikan gizi dalam meningkatkan asupan gizi pada remaja putri yang anemia di kota medan. Jurnal Kesehatan Masyarakat 2016; 11

Syahfitri $Y$, Ernalis $Y$, Restuastuti T. Gambaran status gizi siswa-siswi SMP negeri 13 pekanbaru tahun 2016. JOM 2017;4

Tim Riskesdas 2013. Riskesdas dalam angka indonesia tahun 2013. Jakarta: Lembaga Penerbitan Badan Penelitian dan Pengembangan Kesehatan, 2014

WHO. Global nutrition targets 2025: anaemia policy brief (WHO/NMH/NHD/14.4). Geneva: World Health Organization; 2014 